\title{
ESTIMASI HASIL TANGKAPAN MAKSIMUM SUMBER DAYA UDANG DI LAUT ARAFURA DENGAN MODEL PRODUKSI SURPLUS
}

\author{
Subhat Nurhakim*'
}

\begin{abstract}
ABSTRAK
Kegiatan perikanan udang di Laut Arafura sudah berjalan sejak tahun 60-an, sehingga upaya pengkajian dalam rangka memperoleh manfaat yang berkelanjutan perlu terus dilakukan. Berdasarkan pada data 'hasil tangkapan' dan 'upaya' periode 1991-2002, diperoleh dua jenis indeks kelimpahan stok (CPUE). Indeks pertama adalah 'hasil tangkapan per kapal per tahun' yang berasal dari 1.033 unit kapal penangkap dan indeks kedua adalah 'hasil tangkapan per kapal per hari' yang berasal dari 276.968 hari penangkapan. Pendugaan nilai MSY dan upaya optimum dilakukan melalui aplikasi model produksi surplus. Secara keseluruhan kecenderungan indeks kelimpahan stok periode 1991-2002 menunjukkan pola yang hampir mendatar. Indeks pertama berkisar antara 66,4-70,32 ton per kapal per tahun dengan kelimpahan tertinggi pada tahun 1997 (88,79 ton per kapal per tahun) dan indeks kedua berkisar antara 0,234-0,298 ton per kapal per hari dengan kelimpahan tertinggi terjadi pada tahun $1999(0,328$ ton per kapal per tahun). Nilai dugaan MSY yang diperoleh melalui aplikasi model linier (Schaefer) dari data CPUE berbasis kapal adalah sebesar 29.000 ton, sedangkan dugaan MSY dari data CPUE berbasis hari penangkapan adalah sebesar 34.000 ton. Demikian pula dengan upaya optimum $\left(f_{\text {msy }}\right)$ yang masing-masing sebesar 638 unit kapal, dan 184.000 hari penangkapan. Dugaan MSY yang diperoleh dengan model eksponensial (Fox) dari data CPUE berbasis kapal adalah sebesar 35.000 ton, sedangkan dugaan MSY dari data CPUE berbasis hari penangkapan adalah sebesar 16.000 ton. Upaya optimum $\left(f_{m s y}\right)$ yang diperoleh dengan model eksponensial tersebut masingmasing sebesar 1.000 unit kapal, dan 17.000 hari penangkapan. Dalam rangka investasi jangka panjang adalah nilai dugaan terrendah (lower limit of MSY) perlu diperhatikan, karena pada posisi tersebut dapat dipastikan bahwa secara biologis sumber daya akan mengarah kepada overfishing sedangkan secara ekonomi kegiatan usaha perikanan tersebut akan mengalami kerugian.
\end{abstract}

\section{ABSTRACT: Estimation of the maximum sustainable yield of the shrimp resources in the Arafura Sea using the surplus production model. By: Subhat Nurhakim}

The shrimp resources in the Arafura Sea have been exploited for years, so that stock assessment activities to obtain sustainable benefit from these resources need to be carried out continuously. Based on catch and effort data in 1991-2002 period, two types of the index of abundance in the form of cacth per-unit of effort (CPUE) were calculated. The first index was and the second index was. Both indexes were derived from the catch and effort data collected from 1,033 fishing vessels and 276,968 fishing days. The MSY and optimum effort were estimated through the application of the surplus production model. In general, the trend of the indexes of abundance during the period of 1991-2002 seem to be relatively horizontal. The first index rangied from 66.4-70.32 tonnes/vessel/year with the maximum of 88.79 tonnes/vessel/year occurred in 1997, and the second index ranging from $0.234-0.298$ tonnes/vessel/day with the maximum of 0.328 tonnes/vessel/day was occurred in 1999. The estimated MSY calculated using linier model (Schaefer) based on the effort of fishing vessel number was 29,000 tonnes, while the MSY based on the effort of fishing day number was about 34,000 tonnes. The respective optimum effort $\left(f_{m s y}\right)$ was 638 vessel and 184,000 fishing days. The MSY level estimated using exponential model (Fox) based on both the number of fishing vessel and fishing day was 35,000 and 16,000 tonnes respectively, while the respective optimum effort ( $f_{\text {msy }}$ ) was 1,000 fishing vessels and 17,000 fishing days. In the framework of invesment viability the lower limit of MSY should be carefully considered. Continues fishing operations at this level will undoubtedly lead to the biological overfishing and economic losses.

Key words: $\quad$ stock assessment, shrimp resources, Arafura Sea

\section{PENDAHULUAN}

Tersedianya informasi tentang potensi sumber daya perikanan di suatu perairan merupakan satu dasar bagi langkah pengembangan upaya penangkapan dan pengelolaannya dalam rangka memperoleh manfaat yang berkelanjutan dari sumber daya tersebut. Dalam kenyataan, pengelolaan perikanan modern yang lebih banyak didasarkan atas teori ekosistim, dalam prakteknya lebih dipusatkan pada kegiatan penangkapan terhadap sumber daya yang menjadi sasaran penangkapan (Garcia et. al., 2003), di mana tingkat hasil tangkapan maksimum (MSY) merupakan salah satu titik acuan (reference point) yang hendaknya digunakan sebagai alat retrospeksi dalam mengevaluasi kegiatan perikanan pada masa lalu (Rosenberg \& Restrepo, 1996). Selanjutnya dijelaskan bahwa fakta menunjukkan bahwa pengelolaan yang semata-mata didasarkan atas diperolehnya tingkat MSY banyak mengalami kegagalan. Hal ini antara lain disebabkan selain oleh banyaknya aspek-aspek perikanan yang belum 
difahami juga adanya unsur 'uncertainty' (ketidakpastian) yang langsung atau tidak langsung berpengaruh terhadap kemampuan sumber daya baik dari dalam ataupun dari luar. Beberapa sumber ketidak pastian yang dewasa ini paling berperan adalah dugaan besarnya kelimpahan, struktur model, dan dugaan parameter-parameter dari model tersebut, perilaku pengguna terhadap peraturan, kondisi bio-fisik lingkungan, sosial, politik, dan ekonomi serta tujuan pengelolaan yang ditetapkan pada masa mendatang (Hilborn \& Peterman, 1996).

Kegiatan perikanan di Laut Arafura pada dua dekade terakhir ini telah berkembang demikian pesat dan sangat dinamis tanpa diiringi langkah pengendalian upaya penangkapan yang memadai. Dengan demikian data dan informasi tentang status pemanfaatan sumber daya ikan yang akurat khususnya ikan demersal-udang Laut Arafura dari waktu ke waktu selalu memerlukan 'up dating' (pemutakhiran). Sebagaimana diketahui bahwa ketersediaan data statistik perikanan tahunan yang resmi selalu terlambat sekitar dua tahunan.

Tujuan penyusunan makalah ini adalah sebagai salah satu upaya pembaharuan informasi tentang potensi sumber daya udang di perairan Laut Arafura. Berdasarkan data hasil tangkapan sampai dengan tahun 2000 dugaan hasil tangkapan maksimumnya berada pada sekitar 28.000 ton (Badrudin et. al., 2002). Informasi yang diperoleh diharapkan dapat merupakan salah satu dasar bagi upaya pengelolaan sumber daya udang dalam komunitas sumber daya demersal di Laut Arafura.

\section{BAHAN DAN METODE}

Data 'hasil tangkapan' dan 'upaya' yang dianalisis merupakan hasil tangkapan dari kapal-kapal penangkapan udang dari sejumlah perusahaan penangkapan udang yang termasuk dalam Himpunan Perusahaan Perikanan Indonesia-Gabungan Perusahaan Perikanan Indonesia (HPPI-GAPPINDO) antara periode 1991-2002, sebagaimana disajikan oleh Hernowo (2003). Data tersebut terdiri dari jumlah kapal penangkap, hasil tangkapan udang dari kapal penangkap tersebut, dan jumlah hari operasi penangkapan untuk periode 1991-2002. Data produksi udang tahunan untuk Laut Arafura adalah data yang dicatat dalam statistik perikanan nasional untuk propinsi Maluku dan Irian Jaya periode 1991 . 2000 sebagaimana telah dirangkum dan dianalisis serta dilaporkan oleh Badrudin et. al., (2002). Data produksi udang tahun 2001 diperoleh dari Statistik Perikanan (DJPT, 2003). Dugaan hasil tangkapan maksimum (MSY) dihitung melalui aplikasi model produksi surplus baik model linier dari Schaefer ataupun model eksponensial dari Fox (Sparre \& Venema, 1999).

\section{HASIL DAN BAHASAN}

\section{Kecenderungan Indeks Kelimpahan Stok}

Adanya perubahan indeks kelimpahan stok yang berlangsung secara tahunan merupakan indikator dari adanya pengaruh terhadap suatu komunitas sumber daya ikan di suatu perairan. Dalam hal perairan yang sudah dieksploitasi, pengaruh yang paling utama adalah kegiatan penangkapan.

Berdasarkan data 'hasil tangkapan' dan 'upaya' periode 1991-2002, telah diperoleh dua jenis indeks kelimpahan stok yang berasal dari 1.033 kapal yang dinyatakan dalam bentuk hasil tangkapan per satuan upaya atau CPUE (Gulland, 1983). Indeks pertama adalah hasil tangkapan per kapal per tahun dan indeks kedua adalah hasil tangkapan per kapal per hari di mana kedua indeks tahunan tersebut menujukkan adanya fluktuasi. Antara tahun 19911997 kecenderungan dari indeks pertama tampak naik, sedangkan pada periode berikutnya cenderung menurun (Gambar 1). Secara keseluruhan kecenderungan indeks kelimpahan stok periode 19912002 menunjukkan pola yang hampir mendatar, meskipun ada sedikit kenaikan sebagaimana tampak pada data tahun 1991 sebesar 66,4 ton per kapal per tahun dan pada tahun 2002 adalah sebesar 70,32 ton per kapal per tahun. Demikian juga halnya dengan indeks yang kedua di mana kecenderungan antara periode 1991-2002 secara keseluruhan menunjukkan sedikit pola yang hampir sama, di mana pada 1991 adalah sebesar 0,234 ton per kapal per hari dan pada tahun 2002 naik menjadi sebesar 0,298 ton per kapal per hari. Indeks kelimpahan stok pertama yang tertinggi terjadi pada tahun 1997 sebesar 88,79 ton per kapal per tahun dan indeks kedua tertinggi terjadi pada tahun 1999 dengan indeks sebesar 0,328 ton per kapal per tahun (Lampiran 1).

\section{Perbandingan Indeks Kelimpahan Stok}

Dengan membandingkan dua buah indeks kelimpahan stok pada dua periode yang berlainan dapat diperoleh informasi tentang performansi eksploitasi sumber daya. Dengan menggunakan data perikanan udang Laut Arafura periode 1970-1978 yang merupakan awal masa eksploitasi oleh perusahaan penangkapan 'joint venture' IndonesiaJepang, tampak ada aspek-aspek yang menarik dibandingkan dengan data 1991-2002. Dari data tersebut tampak bahwa rata-rata CPUE (ton per kapal per tahun) periode 1991-2002 baik data yang berbasis ton per kapal per tahun ataupun ton per kapal per hari menunjukkan variasi tahunan yang relatif kecil, yaitu masing-masing sekitar 9,3\% dan $11,1 \%$. Sebaliknya dengan menggunakan jenis data yang sama untuk periode 1970-1978 menunjukkan variasi yang lebih besar, yaitu masing-masing $25,1 \%$ dan $33 \%$. Keadaan tersebut danat ditafsirkan bahwa nado 


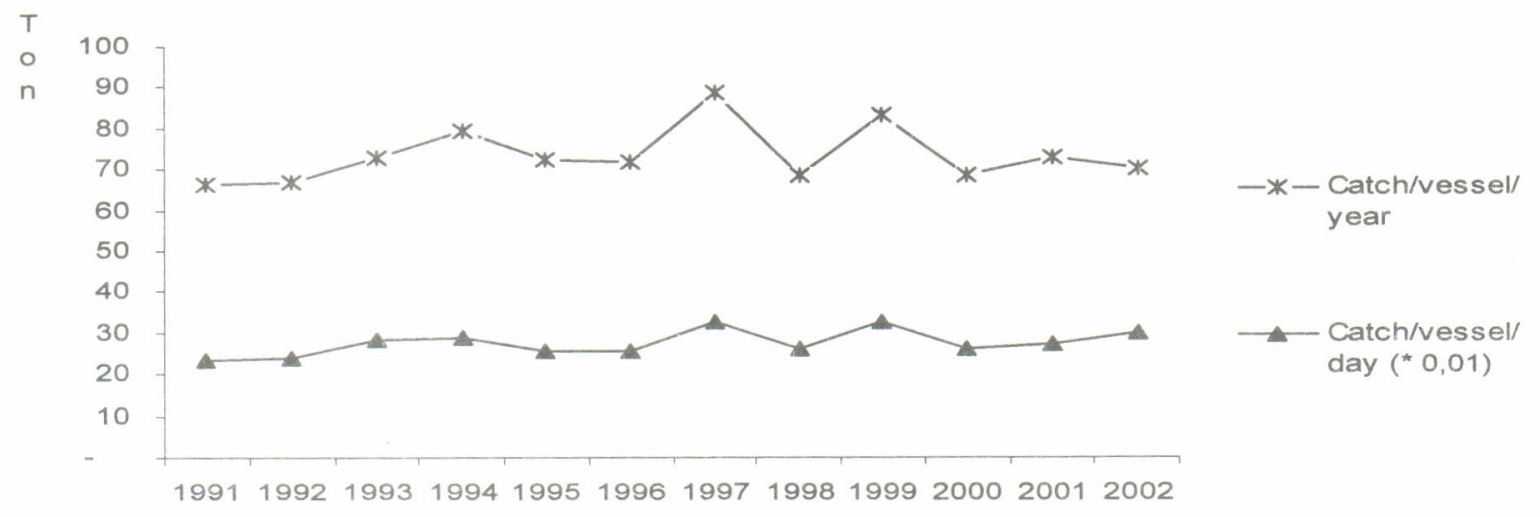

Gambar 1. Kecenderungan dari indeks kelimpahan stok sumber daya perikanan udang di Laut Arafura (1991-2002).

Figure 1. Trend of the index of abundance of the Arafura Sea shrimp fishery resources, 1991-2002.

Tabel 1. Analisis perbandingan 'hasil tangkapan' dan 'upaya' periode 1991-2002 dengan periode 19701978

Table 1. Comparison analyze if catch and effort of 1991-2002 and 1970-1978 period

\begin{tabular}{|c|c|c|c|c|}
\hline \multirow[t]{2}{*}{ Parameter } & \multicolumn{2}{|c|}{ Unit upaya 1991-2002 } & \multicolumn{2}{|c|}{$\begin{array}{l}\text { Unit upaya 1970-1978 } \\
\text { (Unar \& Naamin, 1984) }\end{array}$} \\
\hline & Kapal & Hari & Kapal & Hari \\
\hline Mean CPUE (ton) & 73,52 & 0,275 & 57,49 & 0,290 \\
\hline Simpangan baku & 6,850 & 0,031 & 14,409 & 0,096 \\
\hline Koefisien Variasi (\%) & 9,3 & 11,1 & 25,1 & 33,0 \\
\hline Jumlah kapal & \multicolumn{2}{|c|}{1033} & \multicolumn{2}{|c|}{767} \\
\hline
\end{tabular}

periode 1970-1978 telah terjadi fluktuasi CPUE yang tinggi atau kisaran CPUE yang lebar.

Keadaan tersebut diduga merupakan fenomena umum yang terjadi pada perjalanan sejarah suatu perikanan dalam tahapan berkembang (growthdeveloping) di mana pada waktu tertentu dapat diperoleh hasil tangkapan yang tinggi dan pada waktu lain tanpa mengurangi jumlah upaya diperoleh hasil tangkapan yang rendah. Berbeda dengan keadaan pada awal periode eksploitasi yang menunjukkan adanya variasi CPUE yang tinggi, pada periode 19912002 diduga tidak terjadi suatu lonjakan CPUE yang mencolok sebagaimana ditunjukkan oleh koefisien variasi yang relatif rendah. Dengan kata lain tingkat CPUE pada periode 1991-2002 relatif mapan, sehingga dapat diduga bahwa status perikanan udang secara keseluruhan di Laut Arafura diduga sudah berada padia tahapan pengelolaan (management phase). Pada tahapan tersebut kegiatan pemantauan yang lebih ketat atas jumlah upaya (banyaknya kapal atau hari operasi penangkapan) dengan diringi pemantauan yang lebih rinci atas komposisi jenisjenis udang yang tertangkap. Hal ini sangat penting mengingat seringnya terjadi suatu keadaan di mana secara umum nilai dugaan MSY relatif tetap, padahal hasil tangkapannya didominasi oleh kelompok udang yang berukuran relatif kecil yang nilai ekonominya lebih rendah. Keadaan seperti tersebut telah terjadi pada perikanan demersal di perairan Paparan Sunda, baik di Teluk Thailand ataupun bahkan di Laut Jawa, di mana hasil tangkapannya didominasi oleh kelompok ikan berkuran kecil, seperti jenis-jenis ikan peperek (Leiognathidae). Kelompok ikan berkuran besar seperti jenis-jenis kakap merah (Lutjanidae) sudah amat jarang tertangkap dalam jumlah yang banyak.

\section{Hasil Tangkapan Maksimum (Maximum Sustainable Yield, MSY}

Hasil tangkapan maksimum (MSY) merupakan salah satu titik acuan (reference point) dalam langkah pengelolaan. Dengan diketahuinya dugaan MSY tersebut maka sebagai tindak lanjutnya adalah menghitung angka dugaan upaya optimum ( $\left.f_{\text {msy }}\right)$, yaitu jumlah upaya (upaya) yang diperlukan untuk mendapatkan hasil tangkapan pada tingkat MSY tersebut. Berdasarkan data hasil tangkapan dan upaya yang tersedia telah diperoleh dua jenis data jumlah upaya, yang pertama dinyatakan dalam bentuk jumlah kapal penangkap dan yang kedua adalah jumlah hari penangkapan. Dalam aplikasi model produksi surplus dari Schaefer dinyatakan bahwa hubungan antara total upaya dengan hasil tangkapan per satuan upaya mengikuti persamaan regresi linier dengan slope bertanda negatif (Sparre \& Venema, 1992). 
Tabel 2. Beberapa parameter Model Produksi Surplus-Schaefer (SPM) dari perikanan udang Laut Arafura periode 1991-2002

Table 2. Regression parameters of the Schaefer Surplus Production Model of the Arafura Sea shrimp fisheries 1991-2002

\begin{tabular}{|c|c|c|}
\hline Parameter SPM (Schaefer) & Kapal (fishing vessel) & Hari layar (fishing day) \\
\hline Intercept (a) & 92,849 & 0,3689 \\
\hline Simpangan baku (sa) & 0,000844 & 0,00000004 \\
\hline Slope (b) & $-0,0727$ & $-0,000001$ \\
\hline Simpangan baku (sb) & 0,0368 & 0,0000006 \\
\hline $\begin{array}{l}\text { Correlation coefficient (R) } \\
\text { MSY (ton) }\end{array}$ & $\begin{array}{c}0,53 \\
29,000\end{array}$ & $\begin{array}{c}0,61 \\
34.000\end{array}$ \\
\hline $\begin{array}{l}\text { Lower limit MSY } \\
\text { Upper limit MSY }\end{array}$ & $\begin{array}{r}13.900 \\
230.000\end{array}$ & $\begin{array}{r}14.500 \\
100.000\end{array}$ \\
\hline $\begin{array}{l}\text { Lower limit } f_{m s y} \\
\text { Upper limit } f_{m s y}\end{array}$ & $\begin{array}{r}300 \\
4.900\end{array}$ & $\begin{array}{r}79.000 \\
542.000\end{array}$ \\
\hline
\end{tabular}

Parameter regresi yang diperlukan bagi aplikasi model Schaefer tersebut disajikan pada Tabel 2. Dari tabel tersebut dapat dihitung bahwa nilai dugaan MSY yang diperoleh melalui dua jenis data CPUE berbasis kapal sebesar 29.000 ton lebih kecil dibandingkan dengan MSY yang diperoleh dari data CPUE berbasis hari penangkapan, yaitu sebesar 34.000 ton. Dari tabel tersebut juga tampak bahwa baik kisaran MSY ataupun upaya optimum ( $\left.f_{\text {msy }}\right)$ dari model yang diterapkan kepada data berbasis kapal penangkap jauh lebih sempit (kisaran antara: 13.900-230.000 ton) dibandingkan dengan nilai yang sama dari data berbasis hari operasi penangkapan (kisaran antara: 14.500-100.000 ton). Demikian juga halnya dengan upaya optimum, yang masing-masing sebesar 638 unit kapal (kisaran antara 300-4.900 kapal) dan 189.000 hari layar (kisaran antara: 79.000-542.000 hari layar).

Parameter regresi yang diperoleh dalam aplikasi model eksponensial Fox disajikan pada Tabel 3. Dari tabel tersebut dapat dihitung bahwa nilai dugaan MSY yang diperoleh melalui dua jenis data CPUE berbasis kapal sebesar 35.000 ton dua kali lebih besar dibandingkan dengan MSY yang diperoleh dari data CPUE berbasis hari penangkapan, yang hanya sebesar 16.000 ton.

Dari tabel tersebut juga tampak bahwa kisaran MSY yang diperoleh dari data berbasis kapal penangkap tampak lebih lebar (kisaran antara: 20.500-116.000 ton) dibandingkan dengan nilai yang sama dari data berbasis hari operasi penangkapan (kisaran antara: 9.000-65.700 ton). Demikian juga halnya dengan upaya optimum, yang masing-masing sebesar 1.000 unit kapal (kisaran antara 600-3.300 kapal) dan 17.000 hari layar (kisaran antara: 9.50067.000 hari layar).

Adanya perbedaan tersebut diduga berkaitan, selain dengan tingkat akurasi data yang dianalisis, juga dengan keterbatasan dari model MSY itu yang diterapkan. Sebagaimana diketahui bahwa unit kapal yang digunakan sebagai 'upaya baku' dalam

Tabel 3. Beberapa parameter Model Produksi Surplus-Fox (SPM) dari dari perikanan udang Laut Arafura periode 1991-2002

Table 3. Regression parameters of the Fox Surplus Production Model of the Arafura Sea shrimp fisheries 1991-2002

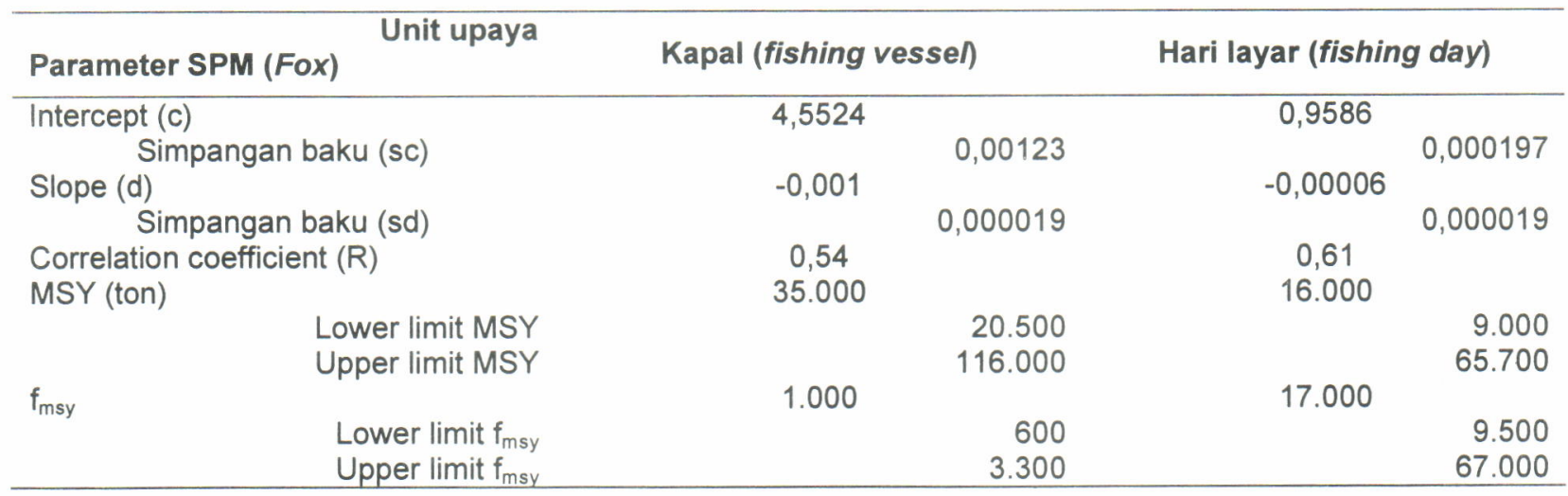


kenyataan masih terdapat perbedaan-perbedaan antara satu unit kapal penangkap tertentu dengan unit kapal penangkap lainnya (seperti Gross Tonnage (GT), Horse Power (HP) mesin, bahan, dan dimensi jaring trawl, dan lainnya). Dari aspek model yang digunakan diperoleh informasi bahwa penggunaan model MSY cenderung mendapatkan nilai dugaan yang lebih tinggi (Larkin, 1977), yang menurut Walters dalam Gillett (2000), bahwa tingginya nilai deviasi MSY tersebut dapat mencapai (as high as) $40 \%$. Dengan demikian, kedua nilai dugaan MSY perikanan udang Laut Arafura baik yang berbasis CPUE unit kapal ataupun CPUE hari penanqkapan masih berada dalam kisaran 40\% tersebut (Catatan: 34.000$29.000=5000 ; \quad 5000 / 29000=0,172(17,2 \%)$ Jika diterapkan kepada nilai yang diperoleh melalui model Fox, tampak bahwa deviasi MSY tersebut tampaknya jauh lebih besar melampaui $>100 \%(19.000 / 16.000)$.

Ditinjau dari aspek investasi jangka panjang, hal yang perlu disadari sebenarnya adalah limit terrendah dari kedua dugaan MSY tersebut, yaitu masingmasing sekitar 13.900 ton dan 14.500 ton. Berdasarkan estimasi Badrudin et. al., ( 2002), dari dugaan MSY periode 1991-2000 sebesar 28.000 ton, diperoleh nilai limit bawah MSY $=17.000$ ton. Dari data dan informasi tersebut dapat diduga bahwa nilai dugaan MSY yang diperoleh berdasarkan data 19912002 secara biologis tidak berbeda dengan hasil estimasi Badrudin et. al., (2002) yang menggunakan data periode 1991-2000. Dapat dipastikan bahwa dengan jumlah kapal penangkap (trawl) yang beroperasi dewasa ini dibandingkan dengan dugaan ketersediaan sumber daya ikan tersebut, secara ekonomis usaha perikanan tersebut tidak akan menguntungkan.

Kegiatan penangkapan udang di Laut Arafura sudah herlangsung sejak lama yaitu saat dimulainya usaha penangkapan udang 'patungan' (joint venture) yaitu pada tahun 60-an. Dari aspek lingkungan perairan Laut Arafura merupakan perairan paparan yang luas dan dangkal dan diduga cukup subur akibat ditunjang oleh sejumlah sungai-sungai besar dan kecil dari daratan Irian Jaya yang bermuara ke perairan tersebut. Sebagaimana dilaporkan oleh Garcia (1984), bahwa di perairan Louisiana yang kemudian juga di Gulf of Mexico pada umumnya, banyaknya hasil tangkapan udang berhubungan erat dengan tingginya aliran sungai (annual river discharge) yang bermuara ke perairan tersebut. Hal serupa juga terjadi dengan keadaan perikanan udang di Gulf of Carpentaria di mana yield yang tinggi dari udang jerbung (Penaeus merguiensis) dapat diperoleh pada tahun-tahun setelah terjadinya curah hujan yang tinggi pada tahun sebelumnya (Staple et. al., 1984).

\section{Kecenderungan Perubahan Komposisi Hasil Tangkapan}

Adanya perubahan komposisi jenis organisme di suatu perairan merupakan reaksi dari adanya pengaruh terhadap komunitas sumber daya tersebut, sebagai upaya komunitas dalam mempertahankan kondisi 'equillibrium'nya. Hal tersebut antara lain dinyatakan dalam bentuk interaksi antar spesies yang ada dalam komunitas ataupun adanya penggantian kelimpahan (species replacement) antar spesiesspesies tersebut. Fenomena tersebut misalnya telah terjadi terhadap komunitas sumber daya demersal di Teluk Thailand, di mana menurunnya kelimpahan sejumlah besar sumber daya ikan demersal telah diiringi oleh meningkatnya kelimpahan sumber daya cumi-cumi (Pope, 1979). Fenomena replacement telah terjadi antara komunitas sumber daya ikan di perairan Laut Utara (North Sea) pada awal abab 19 (Pitcher \& Hart, 1982), di mana menghilangnya populasi ikan demersal sebagai akibat overfishing, telah disusul oleh melimpahnya populasi ikan herring, dan menghilangnya ikan herring telah mengkibatkan munculnya populasi ikan mackerel.

Fenomena yang sama diduga terjadi pula dengan stok udang di Laut Arafura dalam skala yang lebih kecil. Dari Gambar 2, tampak bahwa kelima kelompok udang windu (Penaeus semisulcatus), udang jerbung ( $P$. merguiensis), udang dogol (Metapenaeus spp.), black tiger ( $P$. monodon), dan udang krosok dari

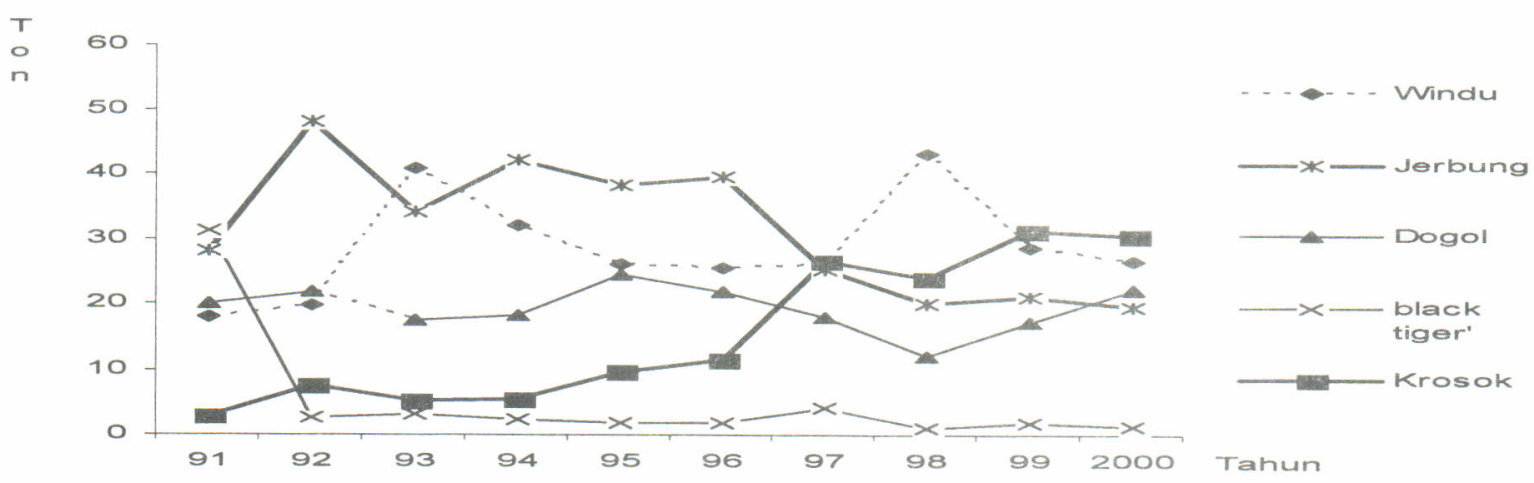

Gambar 2. Perubahan tahunan komposisi jenis udang yang tertangkap di Laut Arafura periode 1991-2000

(Tabel 6, Lampiran 1).

Figure 2. Annual change in catch compositions of the Arafura Sea shrimp fisheries 1991-2000 (Table 6, Annex 1). 
kelompok Metapenaeopsis spp., dan jenis-jenis udang berukuran kecil lainnya menunjukkan reaksi yang berbeda-beda terhadap berbagai pengaruh seperti tekanan penangkapan.

Dari gambar tersebut tampak bahwa annual yield dari kelompok udang jerbung dan black tiger pada periode 1991-2000 menunjukkan kecenderungan untuk menurun, sedangkan udang windu dan udang dogol tampaknya masih bertahan, sebagai tampak pada kecenderungan dari hasil tangkapan udang windu yang masih cenderung naik, meskipun pada tiga tahun terakhir tampak menurun cukup tajam. Berbeda dengan hasil tangkapan udang jerbung dan black tiger dengan kecenderungan yang cenderung menurun, kecenderungan dari kelompok udang krosok pada periode 1991-2000 cenderung naik secara signifikan. Udang krosok adalah kelompok udang yang berukuran kecil yang mempunyai nilai ekonomi relatif rendah dibandingkan dengan kelompok udang berkuran besar lainnya.

\section{KESIMPULAN}

Dari uraian terdahulu dapat dikemukakan beberapa kesimpulan berikut:

1. Berdasarkan data 'hasil tangkapan' dan 'upaya' periode 1991-2002, diperoleh dua jenis indeks kelimpahan stok (hasil tangkapan per satuan upaya, hasil tangkapan per unit upaya, CPUE). Indeks pertama adalah hasil tangkapan per kapal per tahun yang berasal dari 1.033 unit kapal penangkap dan indeks kedua adalah hasil tangkapan per kapal per hari yang berasal dari 276.968 hari penangkapan. Secara keseluruhan kecenderungan indeks kelimpahan stok periode 1991-2002 menunjukkan pola yang hampir mendatar.

2. Dugaan MSY yang diperoleh melalui model linier (Schaefer) dari data CPUE berbasis kapal adalah sebesar 29.000 ton, sedangkan dugaan MSY dari data CPUE berbasis hari penangkapan adalah sebesar 34.000 ton, dengan upaya optimum $\left(f_{\text {msy }}\right)$ masing-masing sebesar 638 unit kapal, dan 184.000 hari penangkapan.

3. Dugaan MSY yang diperoleh dengan model eksponensial (Fox) dari data CPUE berbasis kapal adalah sebesar 35.000 ton, sedangkan dugaan MSY dari data CPUE berbasis hari penangkapan adalah sebesar 16.000 ton dengan upaya optimum $\left(f_{\text {msy }}\right)$ masing-masing sebesar 1.000 unit kapal, dan 17.000 hari penangkapan.

4. Yang perlu diperhatikan dalam rangka investasi jangka panjang adalah nilai dugaan terendah (lower limit of MSY), karena pada posisi tersebut dapat dipastikan bahwa secara biologis sumber daya akan mengarah kepada overfishing sedangkan secara ekonomi kegiatan usaha perikanan tersebut akan mengalami kerugian.

\section{UCAPAN TERIMA KASIH}

Dalam kesempatan ini kami mengucapkan terima kasih kepada Bapak Slamet Hernowo, Sekretaris Jenderal HPPI-GAPPINDO, yang telah menyampaikan data melalui makalahnya yang diserahkan kepada Pusat Riset Perikanan Tangkap, BRKP-DKP. Terima kasih kami sampaikan kepada berbagai pihak yang telah membantu baik moril ataupun material sejak awal pengolahan data hingga tersusunnya makalah ini.

\section{DAFTAR PUSTAKA}

Badrudin, B. Sumiono, \& N. Wirdaningsih. 2002. Laju tangkap, hasil tangkapan maksimum (MSY), dan upaya optimum perikanan udang di perairan Laut Arafura. Jurnal Penelitian Perikanan Indonesia. Edisi Sumber Daya dan Penangkapan. Vol.8 (4) 2002: 23-29.

DJPT. 2003. Statistik perikanan tangkap laut. Direktorat Jenderal Perikanan Tangkap. Departemen Kelautan dan Perikanan.

Garcia, S. M., A. Zerbi, C. Aliaume, T. Do Chi, \& G. Laserre. 2003. The ecosystem approach to fisheries. FAO Fish. Tech. Pap. 443. FAO-UN. Rome. $71 \mathrm{p}$.

Garcia, S. M. 1984. A note on environmental aspects of penaeid shrimp biology and dynamics. In: J. A. Gulland \& B. J. Rothschild (Eds). Penaeid Shrimp; their biology and management. Fishing News Books Ltd. Surrey. England. Pp.: 268-271.

Gillett, R. 2000. Report of the fisheries management specialist: FAO: Indonesia Marine Fisheries Legislation Project. TCP/INS/8922. FAO-UN. Rome. 98p. (Unpublished).

Gulland, J. A. 1983. Fish stock assessment. A Manual of Basic Methods. John Wiley \& Sons.

Hernowo, Slamet. 2003. Produktifas kapal penangkap dengan pukat udang di Laut Arafura. GAPPINDOHPPI. Jakarta. Juli 2003.

Hilborn, R. \& R. M. Peterman. 1996. The development of scientific advice with Incomplete Information in the context of the Precautionary Approach. In: FAO (1996): Precaucionary Approach to Fisheries. Part 2. Scientific Papers. FAO Fish. Tech. Pap. 350/2. Pp. 77-101 
Larkin, P. A. 1977. An epitaph of the concept of maximum sustainable yield. Trans. Amer. Fish. Soc. 106(1): 1-11.

Pitcher, T. J. \& P. J. B. Hart. 1982. Fisheries ecology. croom helm. UK.

Pope, J. G. 1979. Stock assessment in multispecies fisheries with special reference to the trawl fisheries in the gulf of Thailand. South China Sea Fisheries Development and Coordinating Programme. Manila. SCS/DEV/79/19: 106 p.

Rosenberg, A .A. \& V. R. Restrepo. 1996. Precautionary management reference points and management strategies. In: FAO (1996): Precaucionary Approach to Fisheries. Part 2. Scientific Papers. FAO Fish. Tech. Pap. 350/2. Pp. 129-140.

Sparre, P. \& S. C. Venema. 1992. Introduction to tropical fish stock assessment. Part I. Manual. FAO Fish. Tech. Pap. No.306/1.

Sparre, P. \& S. C. Venema. 1999. Introduction to tropical fish stock assessment. Part II. Manual. FAO Fish. Tech. Pap. No.306/2.

Staples, D. J., W. Dall \& D. J. Vance. 1984. Hasil tangkapan prediction of the banana prawn (Penaeus merguiensis) in the south-eastern Gulf of Carpentaria. In: J. A. Gulland \& B. J. Rothschild (Eds). Penaeid Shrimp; their biology and management. Fishing News Books Ltd. Surrey. England. Pp.: 259-267.

Unar, M. \& N. Naamin. 1984. A review of the Indonesian shrimp fisheries and their management. In: J. A. Gulland \& B. J. Rothschild (Eds). Penaeid Shrimp; their biology and management. Fishing News Books Ltd. Surrey. England. Pp.: 104-110. 
Lampiran 1 (Annex 1).

Tabel 4. Data hasil tangkapan dan upaya perikanan udang Laut Arafura, 1991-2002

Table 4. Catch and effort data of shrimps fisheries of Arafura sea in 1991-2002

\begin{tabular}{|c|c|c|c|c|c|c|c|c|}
\hline Tahun & $\begin{array}{c}\text { Hasil } \\
\text { tangkapan } \\
(\mathrm{t})\end{array}$ & $\begin{array}{c}\text { No. } \\
\text { fishing } \\
\text { vessel }\end{array}$ & $\begin{array}{l}\text { No. } \\
\text { fishing } \\
\text { days }\end{array}$ & $\begin{array}{c}\text { Total hasil } \\
\text { tangkapan } \\
\text { (t) }\end{array}$ & $\begin{array}{c}\text { Hasil } \\
\text { tangkapan/ } \\
\text { vessel }(\mathrm{t})\end{array}$ & $\begin{array}{c}\text { Hasil } \\
\text { tangkapan/ } \\
\text { day }(\mathrm{t})\end{array}$ & $\begin{array}{c}\text { Total } \\
\text { upaya } \\
\text { (vesse) }\end{array}$ & $\begin{array}{l}\text { Total } \\
\text { Upaya } \\
\text { (days) }\end{array}$ \\
\hline & A & B & C & D & $E=A / B$ & $F=A / C$ & D/E & D/F \\
\hline 1991 & 5843,35 & 88 & 24.988 & 19.657 & 66,40 & 0,234 & 296,03 & 84.060 \\
\hline 1992 & 6169,66 & 92 & 25.732 & 18.076 & 67,06 & 0,240 & 269,54 & 75.390 \\
\hline 1993 & 6354,81 & 87 & 22.512 & 13.990 & 73,04 & 0,282 & 191,53 & 49.560 \\
\hline 1994 & 6682,68 & 84 & 23.113 & 14.269 & 79,56 & 0,289 & 179,36 & 49.351 \\
\hline 1995 & 6219,84 & 86 & 24.179 & 18.503 & 72,32 & 0,257 & 255,84 & 71.929 \\
\hline 1996 & 6117,21 & 85 & 24.118 & 20.780 & 71,97 & 0,254 & 288,74 & 81.928 \\
\hline 1997 & 6748,41 & 76 & 20.788 & 23.053 & 88,79 & 0,325 & 259,62 & 71.013 \\
\hline 1998 & 5877,75 & 86 & 22.619 & 21.472 & 68,35 & 0,260 & 314,17 & 82.629 \\
\hline 1999 & 7214,91 & 87 & 21.974 & 16.976 & 82,93 & 0,328 & 204,70 & 51.703 \\
\hline 2000 & 5702,68 & 83 & 22.026 & 20.823 & 68,71 & 0,259 & 303,07 & 80.427 \\
\hline 2001 & 5819,59 & 80 & 21.542 & 24.235 & 72,74 & 0,270 & 333,15 & 89.709 \\
\hline \multirow[t]{4}{*}{2002} & 6961,93 & 99 & 23.377 & 20.678 & 70,32 & 0,298 & 294,05 & 69.433 \\
\hline & $\Sigma=$ & 1033 & 276.968 & Mean & 73,52 & 0,275 & 265,82 & 71.428 \\
\hline & & & & St.dev. & 6,85 & 0,031 & 49,89 & $14.094,62$ \\
\hline & & & & $\begin{array}{c}\text { Coef. Var } \\
(\%)\end{array}$ & 9,3 & 11,1 & & \\
\hline
\end{tabular}

Tabel 5. Data hasil tangkapan dan upaya perikanan udang Laut Arafura, 1970-1978

Table 5. $\quad$ Catch and effort data of shrimps fisheries of Arafura sea in 1970-1978

\begin{tabular}{|c|c|c|c|c|c|}
\hline & $\begin{array}{c}\text { No.fishing } \\
\text { vessel }\end{array}$ & $\begin{array}{c}\text { No.fishing } \\
\text { days }\end{array}$ & $\begin{array}{l}\text { Hasil tangkapan } \\
\text { (t) }\end{array}$ & $\begin{array}{c}\text { Hasil } \\
\text { tangkapan/vessel } \\
(\mathrm{t})\end{array}$ & $\begin{array}{c}\text { Hasil } \\
\text { tangkapan/day } \\
\text { (t) }\end{array}$ \\
\hline 1970 & 17 & 2.202 & 812,4 & 47.788 & 0,369 \\
\hline 1971 & 42 & 6.684 & 2493,3 & 59.364 & 0,373 \\
\hline 1972 & 65 & 12.418 & 4358,6 & 67.055 & 0,351 \\
\hline 1973 & 79 & 16.019 & 6891,5 & 87.234 & 0,430 \\
\hline 1974 & 95 & 21.552 & 6532 & 68.758 & 0,303 \\
\hline 1975 & 104 & 24.570 & 4737,1 & 45.549 & 0,193 \\
\hline 1976 & 120 & 29.441 & 5567,4 & 46.395 & 0,189 \\
\hline 1977 & 120 & 28.575 & 5687,7 & 47.398 & 0,199 \\
\hline 1978 & 125 & 30.172 & 5984 & 47.872 & 0,198 \\
\hline \multirow[t]{3}{*}{$\Sigma=$} & 767 & 171.633 & Mean & 57.490 & 0,290 \\
\hline & & & St.dev. & 14.409 & 0,096 \\
\hline & & & Coef. Var (\%) & 25,1 & 33,0 \\
\hline
\end{tabular}


Tabel 6. Komposisi hasil tangkapan udang di Laut Arafura periode 1991-2000.

Table 6. Catch composition of shrimps in the Arafura Sea in 1991-2000

\begin{tabular}{cccccc}
\hline Tahun & \% tiger shrimp & $\begin{array}{c}\text { \% banana } \\
\text { shrimp }\end{array}$ & \% endeavour & \% black tiger & \% others \\
\hline 1991 & 17,8 & 28,1 & 20 & 31,2 & 2,9 \\
1992 & 19,7 & 48,1 & 21,9 & 2,6 & 7,6 \\
1993 & 40,7 & 33,9 & 17,3 & 3,1 & 5,1 \\
1994 & 32 & 42 & 18,1 & 2,4 & 5,4 \\
1995 & 25,9 & 38,2 & 24,5 & 1,7 & 9,6 \\
1996 & 25,5 & 39,6 & 21,9 & 1,8 & 11,3 \\
1997 & 26,1 & 25,3 & 17,8 & 4,2 & 26,6 \\
1998 & 43,1 & 20 & 12 & 1,1 & 23,8 \\
1999 & 28,7 & 21,1 & 17,1 & 1,9 & 31,2 \\
2000 & 26,6 & 19,5 & 22 & 1,4 & 30,5 \\
\hline
\end{tabular}

(Sumber: Badrudin et. al., 2002) 
